States remained a sole hegemon in the new system of international relations. China has turned into a "global workshop", which has increased its financial, economic and military-political influence on various processes worldwide and in the South Asian region in particular. India and China are suffering from the threat of international terrorism. The United States are trying to keep their relevance in terms of Asian security, which is no less important to this country than Euro-Atlantic security. India has no intention to develop its strategic relations with the US through radical deterioration of the Indian-Chinese relations, which were settled with great complexity. However, India remains interested in maximal weakening of the US-Pakistani relations, especially in the military-technical sphere.

Key words: India, USA, bipolar system of international relations, unipolar system of international relations, strategic partnership, Non-Aligned Movement, China, Pakistan.

\section{УДК 94: 327] (55: 73: 5 - 191.2) “19/20"}

http://doi.org/10.17721/2521-1706.2017.03.84-92

\section{Galyna Mingazutdinova,}

$\mathrm{PhD}$ (History),

Historian of the Science and Research Department

(History Department, Taras Shevchenko

National University of Kyiv)

\title{
THE US - IRANIAN STRATEGIC COMPETITION IN CENTRAL ASIA
}

\begin{abstract}
In late 1990s - early 2000s, the post-Soviet countries of Central Asia became an arena of specific geopolitical standoff, also known as The New Great Game. The vanishing of the USSR from the political map resulted in the emergence of the newly independent states and of the new external powers interested in occupying the niche of the bygone superpower. To counter the United States' presence in the region, a number of potential competitors rose. Among them, China, Russia, Turkey and Iran shall be named. While the USA promoted their foreign policy towards Central Asia proceeding from the contemporary history, their respective opponents, namely Iran, had a huge historical background to justify its relations with Tajikistan, Kazakhstan, Uzbekistan, Turkmenistan and Kyrgyzstan. However, the existence of shared historical heritage had few in common with the actual geopolitical success in the region. Firstly, the Central Asian countries themselves decided to keep to the multilateral foreign policy and receiving any kind of assistance from the external partners to promote themselves on the international arena without taking any heritage background into consideration. Secondly, external financial and military assistance governed the issue of who may dominate in Central Asia. Thirdly, the general geopolitical interests of the great powers in Central Asia happened to be deeply interrelated and claimed more for cooperation that to competition to implement them. To this end, a mixture of joint and opposed actions taken by the superpowers in Central Asia proved to be inevitable.
\end{abstract}

Key Words: USA, Central Asia, Iran, Middle East, cooperation.

Introduction. The collapse of the USSR brought about the political vaccum in the Central Asia with fast and to some extent unexpected gaining of sovereignty by the republics of the Soviet Middle Asia. The former Soviet republics de-facto remained in the sphere of influence of Russia. However, indeed the brand new actors began to percolate through the region. Turkey, 
China, Iran, India, Pakistan and the United States started fostering their interests in the Middle Asia.

The emergence of the new competitors to handle their influence is strongly connected with a desire to carry out their national interests, inter alia in the sphere of economy. Thus, Turkey serves as a transit actor in Baku-Tbilisi-Cheykhan pipeline, Nabucco and the South Caucasus stream; China spreads its influence prima facie in the energy sector; Iran is willing to partake in creation of the Caspian-Persian pipeline. Although the liaisons of the US with the region are not that comprehensive as those of Russia or China, Washington has strengthened its economic, political and strategic influence in the Middle Asia. The US shows itself as a superpower in Eurasia creating a new global system. The foreign policy of the US is based on theoretical works of geopolitics declaring Eurasia as a supercontinent which plays a role of the so-called axis. To this end, a state that takes over the supercontinent shall take over as well two out of three most developed economic regions: Western Europe, Eastern Asia and the Middle East. With an eye to such a theory, a multilateral geopolitical activity is being held by the US in the basin of Caspian Sea and in the ex-Soviet Middle Asia.

In its turn, Iran has been shaping its policy towards Central Asia both on the historical and geopolitical grounds. Thus, the lands shaping the modern-day borders of Turkmenistan, Kazakhstan, Uzbekistan, Tajikistan and Kyrgyzstan represent an important part of the Iranian historical heritage. Having been an integral part of a number of successive Middle Eastern empires' fief, Central Asia is as well a crucial element of the ideological concept of the Aryan theory. The latter explains the region as a cradle of the legendary Aryan peoples, from which the name of Iran itself is believed to be coming from. In the practical and political sense, Central Asia is potentially a reliable alternative to the Middle East where the Iranian influence is far from being strong and decisive.

Finally, the newly independent states of Central Asia preferred to stick with the multi-faceted external policy at large, fruitfully collaborating with a number of regional superpower challengers, in particular, with Tehran and Washington. Under these conditions, the USA and Iran have found themselves in a state of regional competition for the souls of Central Asia.

The issues of bilateral relations of Central Asia and the US, Central Asia and Iran and the Iran-American strategic competition (together with, partially, coordination of forces on certain aspects of external policy) have been subject to examination by the scholars of the globe since early 1990s. The role of Central Asian countries in the American foreign policy narrative have been unfolded in the research works by G.Fuller [1], M.Mayer [2], J.Davis, M.Sweeney [3], S.Blank [4], S.Akbarzaheh [5] and N.MacFarlane [6]. The Iranian path in the Central Asian intercourse is deeply explored by E.Wastnidge [7], A.Shafiev [8], N.Kozhanov [9], S.Peyrouse [10] etc. E.Fitzgerald [11], M.Katz [12] and E.Rumer [13] have contributed to the analysis of basic forms of Washington-Tehran standoff in Central Asia.

The significance of Central Asia for the United States' foreign policy and strategy has been primarily determined by the proximity of the latter to Afghanistan. It is pretty clear-cut that the region itself constitutes a unique corridor that provides access to this oecumene of global terrorism. Such access became even more valuable within the framework of the Operation Enduring Freedom against the Taliban announced on October 7, 2001 by President George W. Bush [14, P. 96]. This was the crucial time for the American strategy abroad when groundbreaking decisions have been made. As a 
result, Central Asia turned into a decisive element of the Washington's regional policy, given its geographical position and propinquity to the terroristic bull's eye. As part of Enduring Freedom, two strategically important airbases in Uzbekistan and Kyrgyzstan, Khanabad and Manas respectively, have been in effect: both served to provide troops and cargo transportation to the scene of operations. Tajikistan as well hosted the allies' aircrafts on the Kulyab airbase and contributed to the non-proliferation and counternarcotics spheres of cooperation. The relations between the U.S. and Kazakhstan reached a new level within the framework of Enduring Freedom as well: Astana granted access for the American aircrafts' fueling and landing in the airports of the Kazakh capital and made an airport in Shymkent a part of operational activity of the allies in July 2002. Moreover, Kazakhstan hosted a $12^{\text {th }}$ session of the International Contact Group within the scope of the Bonn agreements on Afghanistan [22].

According to Colin Powell, from 2001 the criticality of Central Asia, as well as the American military presence in the region became exclusively prominent as never before [15, P. 22]. So, today the military aspect of America's presence in Central Asia within the Afghan operations remains pivotal. On top of that, the rising tensions between the USA and Pakistan evoked another productive side of Washington's cooperation with Central Asia: the latter is now viewed in the capacity of a transit route for NATO and American equipment to the Afghan seat of war [11, P. 14]. In this respect, Uzbekistan have become the center of the so-called "Northern Distribution Network" - a number of commercial territorial and air tracks of non-lethal weapons supplies to the NATO and the U.S.' contingents in Afghanistan from Europe via Russia, Caucasus and Central Asia. About 75 per cent of entire supply package have been transported to the allies through the NDN since 2011 [19]. Hairatan Gate of Uzbekistan has been one of the most consequential transportation node of the network due to its geographical position which opened access to the railways towards Mazar-E-Sharif [20].

One can't underestimate Central Asia both as a famous Heartland, the world domination guarantee, and as specific geographical unity situated between the toughest regional players of the late $20^{\text {th }}$ - early $21^{\text {st }}$ centuries - those of China, India, Russia, Iran and Pakistan. Beside its military importance for the Afghanistan campaign with its transitional and geographical consideration, Central Asia as well has been regarded by the U.S. as a key to implement their broader geopolitical interests. Undoubted, Central Asia remained critical for the USA due to its large energy potential, untold natural wealth and broad network of transport ways geared to deliver gas and oil to the importing countries [14, P. 405]. Obviously, the rise of any external competitor in the region would result in Washington's losing its unique access to the region. This, in its turn, would reflect on the more global American interests in Asia, particularly in the Middle East [16, P. 3]. To this end, the USA is destined to face and withstand the regional counterparts who have cultural, geopolitical and economic liaisons with Central Asia in their bag. What is more, the idea of fostering stability and security in Central Asia might need some sort of cooperation between Washington and any of its regional opponents (namely, Iran) $[13$, P. 1].

Unlike the U.S., Iran did have a deep cultural, ethnic and religious background to back its own contemporary interests. For instance, sharing both territorial and maritime borders with Kazakhstan and Turkmenistan is of great importance to the geographical context of the Tehran's relations with Central Asia. Besides, Iran is geographically tied to the Central Asian runs-out to the Gulf, and this is the very sphere where the political 
weight of Iran is completely obvious and, what is more important for the regional geopolitics, shows a descent alternative to Russia, another traditional player in Central Asia [11, P. 14]. In this respect, Iran's geographical position played into the Central Asia's hands, for the former was an obvious choice for developing the new states' economies by cooperating with its Middle Eastern neighbor. However, regardless of the speculations emerging in the West, Tehran won't try to impose the spread of Islamic ideals upon the newly independent states due to lack of respective support within the Central Asian societies which became deeply secular and borderline atheistic after decades of Soviet domination. Instead, Iran preferred to develop pragmatic approach to create comfortable conditions under which the former would cooperate with the five states of the region and provide friendly relations with the post-Soviet Central Asian governments, promoting diplomatic and trade relations therewith [17, P. 22]. Thus, the materialism was a cornerstone for Iran within the framework of the Tajik civil war, when Tehran granted support to the formerly communist part of the conflict against the Islamic opposition [12, P. 2]. Beside that, among all Central Asian countries, Iran invests in Tajikistan the most, together with China. Within decades, Iran managed to have created a steadily high level of cooperation with this culturally similar state in the sphere of economics, defense, regional security and industry.

Another exceptionally pragmatic element of the Iranian activity and strengthening its foothold in Central Asia was the Afghan factor. The movement of Taliban that was in power in Afghanistan gave serious concerns both to Iran and Central Asia and their security: with its providing assistance to the radicals of the Islamic Movement of Uzbekistan and supporting their ideas of the Sunni Islamic revolution, the Taliban wouldn't conceal its hostility and menace towards Iran in the first place. So, Iran was all too well interested in creating space of peace and security in Central Asia, the border of Afghanistan. In 2001, K.Kharrazzi who then was in office as a Minister of Foreign Affairs, declared Central Asia as a pivot of the Iranian foreign policy [21, P. 89]. And in 2016, President H.Rouhani once again underlined the importance of security cooperation with the region, basically with Turkmenistan. The latter was backed by the reasons of partnership and Ashgabat's attitude towards the Sunnis: firstly, Tehran has picked Turkmenistan its vital partner in combating Islamic extreme movements reaching out from Afghanistan to Central Asia. Secondly, the Turkmen hostility towards the ISIS and the Sunni groups works in Iran's favor when it comes to security issues [26]. Apart from it, Iran generally was searching for a sort of Central Asian mediator to restore its relations with Afghanistan after the downfall of the Taliban government. In their turn, the Central Asian states are interested in the peaceful status quo and their aspirations do have much in common with those expressed by Iran in this sphere.

Through late $20^{\text {th }}-$ early $21^{\text {st }}$ centuries Iran managed to have developed its policy in Central Asia to an assertive level and in shaping the energy factor as one of the most crucial ones in this respect, with deciding on its own function in providing the landlocked states with important natural resources. Moreover, Iran accomplished a task of selfproviding with petroleum and gas. For instance, it was Iran who became a destination of the first Turkmen gas pipeline that exports natural gas beyond Central Asia and Russia [11, P. 27]. Turkmenistan as well has become Iran's partner in constructing the KorpejeKordkuy gas pipeline [23]. Pragmatism as well lied at the heart of Iran's desire to baffle the United States' attempts to evolve to a decisive superpower in the Central Asian region, with its replacing the bygone Soviet Union in this role and isolating Iran at the 
same time [18, P. 64]. Indeed, the collapse of the USSR gave basis to serious concerns of Iran about it own security situation: Tehran suffered a serious loss of an ally in resisting the America's influence in the region. To this end, Iran has left tête-à-tête with Washington and commenced to search ways for establishing friendly relations with the newly independent states.

However, contemporary impact of Iran in Central Asian affairs seems rather blur first and foremost due to the attitude that the region's governments express thereto. Thus, Turkmenistan who is the basic economic partner of Iran in Central Asia has much work to do with Turkish and Israeli companies which are somewhat opposed to the Iranian interests towards Central Asia; accordingly, Kazakhstan and China economic relations pose a strong competition to those with Iran. Beside that, through decades Kazakhstan succeeded in getting closer to the Iran's counterpart - the U.S. With Astana's support to the American sanctions imposed on Iran upon its nuclear program, Kazakhstan has fallen to the background of Tehran's foothold in Central Asia [11, P. 19]. Uzbekistan shows some concerns about the possible fostering of Islamic factor by Tehran; to some extent this factor prevented Uzbekistan from closer military and security cooperation with Iran. Alongside this, Washington managed to have shaped stable diplomatic and strategic relations with Uzbekistan in front of Tehran (particularly, due to the NDN importance to the U.S. and the abovementioned role of Uzbekistan therein). There as well exists an entanglement in promoting security cooperation between Iran and Tajikistan, for the latter being still bound by a series of respective agreements with Moscow. And let alone the rapprochement of the Obama administration with Turkmenistan on the grounds of energy cooperation [24] and the Turkmen government's concerns about the Islamic fundamentalism prospering in Iran. Given these two factors, it is Turkmenistan that might become a center of the U.S. - Iran competition in the region for a nearest decade at least: with its steps towards the development of hydrocarbon resources and its religious neutrality towards Central Asia, Washington might be regarded as a profitable investor and alternative to Tehran with whom Turkmenistan had some difficulties in the sphere of energy (such as price and supply issues) [11, P. 29]. The prolongation of the international embargo didn't bode well for Iran - Turkmenistan hydrocarbon distribution either [25, P. 9].

When it comes to the Afghan issues, Iran may be as well officially called a lost card in the post-anti-terrorist game of the great powers in Central Asia. Regardless of the Tehran's adherence to the principles of regional stabilization through the elimination of the Taliban menace, Iran has in fact been removed by the U.S. from its closest cultural and historical associate - Tajikistan. Together with Uzbekistan, this country has become a true stronghold for the USA and its allies, with its opening Kulyab airport in the Southern Tajikistan for the troops partaking in Enduring Freedom. By cooperating with Washington in the Afghan context, Dushanbe used each and every moment of its involvement in the counter-terrorist combat to improve its international reputation and position itself as a reliable partner in military and political activities. And with Turkmenistan's, the only officially neutral state of Central Asia, opening its airspace for American military aircraft and creating a transit location therefore provided Iran with serious concerns about the America's rising influence both in Middle East and in Central Asia. Finally, the financial factor is one of the most decisive for the Central Asian countries to choose between Washington and Tehran: in 2010s, the American energy companies operating huge material potential began to show more and more interest in 
implementing shared energy projects with the region (with Turkmenistan in the first place), and the U.S. is still influential when it comes to external finance help to the Central Asian social and economic life [9].

Although Iran is facing serious challenges in its impact on Central Asia due to the steady American presence in the region, there used to be a hope for cooperation exactly in the military sphere between Tehran and Washington. For both sides showed hostility towards the regime of Taliban, they had an opportunity to coordinate its actions in Afghanistan through granting humanitarian and military assistance to the U.S. by Iran. However, the departure of a common rival removed any hints on further cooperation between the two countries when it comes to the Afghan issue. What is more, the Washington's Iraqi campaign of 2003 has put the clock back in the American - Iranian relations and restored the "frienemies" condition in their political coexistence. The hostility kept on growing when the Unites States backed up the Kyrgyz revolution of 2005 and lashed out at the Uzbek powers after the events in Andijon. To this end, not only did Iran oppose the Sunni ideological expansion from Afghanistan in Central Asia, but as well turned against the democratic ideas promoted by the U.S. in the region [12, P.2].

Conclusion. Nowadays Iran remains challenging for the United States' following presence in Central Asia. Given its cultural and historic heritage shared with the region, as well as its potential as an exporter of region's natural resources (primarily - gas and oil) underlines its steady status as a Central Asia's partner in political and economic life thereof. Even without any threat Iran might pose for the USA in the military sphere, its economic and cultural impact still threatens and keeps America's regional activities on tenterhooks. And vice versa, the deem prospects of America's leaving Central Asia threatens the Iranian activities and stability in the region, for without the American troops the Sunnis might rise once again in Central Asia and show their claws to Tehran. This irony brings the USA and Iran to the edge of love and hate with the ultimate necessity to promote cooperation in the region and bear the Central Asian security status quo which would tolerate both sides of the contemporary competition. For instance, the U.S. may profit from cooperating with Tehran by lowering the Beijing's impact on Central Asia and Afghanistan. Likewise, both sides are interested in limiting the Russian growing influence in Central Asia and the Caucasus [27]. Specifically, Iran's potential benefit from shaping regional friendship with Washington might bring restrictions for Moscow's domination in the Caspian basin. Anyway, one can't exaggerate the prospects of such cooperation to come, for there still is a number of challenges to accept and some difficult choices to be made in this respect by both.

\section{Sources}

1. Fuller G. Central Asia. The New Geopolitics / G.Fuller. - National Defense Research Institute. - Santa Monica, 1992. - 86 p.

2. Mayer M. US Grand Strategy and Central Asia: Merging Geopolitics and Ideology / M.Mayer. - Defence and Security Studies. - Oslo, 2008. - 143 p.

3. Davis J., Sweeney M. Central Asia in U.S. Strategy and Operational Planning: Where Do We Go From Here? / J.Davis, M.Sweeney. - The Institute for Foreign Policy Analysis. - Washington, D.C., February 2004. -83 p.

4. Blank S. After Two World Wars: Reflections on the American Strategic Revolution in Central Asia / S.Blank. - Strategic Studies Institute. - 2005. - 61 p. 
5. Akbarzadeh S. Uzbekistan and the United States. Authoritarism, Islamism and Washington's Security Agenda / S.Akbarzadeh. - London: Zed Books, 2005. - 166 p.

6. MacFarlane N. The United States and Regionalism in Central Asia / N.MacFarlane // International Affairs. - 80, 3 (2004). - p. $447-461$.

7. Wastnidge E. Central Asia in the Iranian geopolitical imagination / E. Wastnidge // Cambridge Journal of Eurasian Studies. - 1.\#YRJ04, 2017. - 13 p.

8. Shafiev A. Iran and Tajikistan: A Story of Love and Hate /A.Shafiev // Central Asia Policy Brief. - February 2016. - No. 34. - 5 p.

9. Kozhanov N. Iran is Struggle for Influence in Post-Soviet Central Asia: Main Goals and Driving Factors [Electronic Resource] - Mode of Access: http://www.eisa-net.org/bebruga/eisa/files/events/warsaw2013/paper_Kozhanov.pdf (Last Access: June 5, 2017). - Title from the Screen.

10. Peyrouse S. Iran's Growing Role in Central Asia? Geopolitical, Economic and Political Profit and Loss Account [Electronic Resource] - Mode of Access: http://studies.aljazeera.net/en/dossiers/2014/04/2014416940377354.html (Last Access: June 5, 2017). Title from the Screen.

11. Fitzgerald E., Vira V. U.S. and Iranian Strategic Competition: Competition in Afghanistan, Central Asia and Pakistan /E. Fitzgerald, V.Vira. - Washington D.C.: September 12, 2011. - Center for Strategic and International Studies. $-34 \mathrm{p}$.

12. Katz M.N. Russia, Iran and Central Asia: Impact of the U.S. Withdrawal from Afghanistan / M.Katz // Iran Regional Forum. - February 2013, No. 3. - 4 p.

13. Rumer E. Flashman's Revenge: Central Asia after September 11 /E.Rumer // Strategic Forum. - December 2002. - No. 195. - 8 p.

14. Rice C. No Higher Honor: A Memoir of My Years in Washington / C.Rice. - New York: Broadway Paperbacks, 2011. -784 p.

15. McMullin R. Caspian Sea Regional Security in the XXIst Century / R.McMullin. - US Army War College, 7 April 2003. - 45 p.

16. Rumer E. China, Russia and the Balance of Power in Central Asia / E.Rumer // Strategic Forum, № 223. -November 2006. -8 p.

17. Atkin M. Tajikistan's Relations with Iran and Afghanistan /M.Atkin. - Washington D.C., November 9, 1992. - The National Council for Soviet and East European Research. - 40 p.

18. Grogan M. National Security Imperatives and the Neorealist State: Iran and Realpolitik. Thesis / Michael Grogan. - Naval Postgraduate School: Monterey, California, 2000. - 211 p.

19. Central Asia and the Transition in Afghanistan. A Majority Staff Report Prepared for the Use of the Committee on Foreign Relations. United States Senate. One Hundred Twelfth Congress, First Session, December 19, 2011 [Electronic Resource] - Mode of Access: http://www.gpo.gov/fdsys/pkg/CPRT-112SPRT71639/html/CPRT-112SPRT71639.htm (Last access: December 12, 2013). - Title from the Screen.

20. Myers P. Why Hairatan Gate Matters [Electronic Resource] - Mode of Access: http://www.dcvelocity.com/articles/20111118why_hairatan_gate_matters (Last access: November 11, 2013). - Title from the Screen.

21. Peyrouse S., Ibraimov S. Iran's Central Asia Temptations / S. Peyrouse, S.Ibraimov // Current Trends in Islamist Ideology. - April 2010. - Vol. 10. - P. 87 - 101.

22. International Contact Group on Afghanistan held meeting of unprecedented level - Kazakh FM [Electronic Resource] - Mode of Access: http://inform.kz/eng/article/2419432 (Last access: December 20, 2013). - Title from the Screen.

23. Turkmenistan Plans Gas Pipeline to Iran [Electronic Resource] - Mode of Access: http://qctimes.com/business/investment/turkmenistan-plans-gas-pipeline-to-iran/article_fb11d4a0-6f3d11de-8f4b-001cc4c03286.html (Last Access: June 5, 2017). - Title from the Screen.

24. President: Turkmenistan Attaches Great Importance to U.S. Cooperation [Electronic Resource] - Mode of Access: http://en.chrono-tm.org/2014/02/president-turkmenistan-attaches-greatimportance-to-u-s-cooperation (Last Access: June 5, 2017). - Title from the Screen.

25. Bendini R. Turkmenistan: Selected Trade and Economic Issues. Policy Briefing / R.Bendini. Brussels, 2013. - Directorate-General for External Policies. - 11 p. 
26. Ramani S. Has Iran Finally Found a Security Partner in Central Asia? [Electronic Resource] Mode of Access: http://thediplomat.com/2016/05/has-iran-finally-found-a-security-partner-in-central-asia (Last Access: June 5, 2017). - Title from the Screen.

27. Carpenter T.G. The West and Iran in Central Asia: More Competition of Coordination? [Electronic Resource] - Mode of Access: https://www.boulevard-exterieur.com/The-West-and-Iran-inCentral-Asia-more-competition-or-coordination.html (Last Access: June 5, 2017). - Title from the Screen.

\section{References}

1. FULlER, G. (1992) Central Asia. The New Geopolitics. Santa Monica: National Defense Research Institute.

2. MAYER, M. (2008) US Grand Strategy and Central Asia: Merging Geopolitics and Ideology. Oslo: Defense and Security Studies.

3. DAVIS, J., SWEENEY, M. (2004) Central Asia in U.S. Strategy and Operational Planning: Where Do We Go From Here? Washington, D.C.: The Institute for Foreign Policy Analysis.

4. BLANK, S. (2005) After Two World Wars: Reflections on the American Strategic Revolution in Central Asia. Carlisle: Strategic Studies Institute.

5. AKBARZADEH, S. (2005) Uzbekistan and the United States. Authoritarism, Islamism and Washington's Security Agenda. London: Zed Books, 2005.

6. MACFARLANE, N. (2004) The United States and Regionalism in Central Asia. International Affairs. No. 80, 3. P. $447-461$.

7. WASTNIDGE, E. (2017) Central Asia in the Iranian geopolitical imagination. Cambridge Journal of Eurasian Studies. 1.\#YRJ04.

8. SHAFIEV, A. (2016) Iran and Tajikistan: A Story of Love and Hate. Central Asia Policy Brief. No. 34.

9. KOZHANOV, N. Iran is Struggle for Influence in Post-Soviet Central Asia: Main Goals and Driving Factors [Online] - Available from: http://www.eisa-net.org/bebruga/eisa/files/events/warsaw2013/paper_Kozhanov.pdf (Accessed June 5, 2017).

10. PEYROUSE, S. Iran's Growing Role in Central Asia? Geopolitical, Economic and Political Profit and Loss Account [Online] - Available from: http://studies.aljazeera.net/en/dossiers/2014/04/2014416940377354.html (Accessed June 5, 2017).

11. FITZGERALD, E., VIRA, V. (2011) U.S. and Iranian Strategic Competition: Competition in Afghanistan, Central Asia and Pakistan. Washington D.C.: Center for Strategic and International Studies.

12. KATZ, M.N. (2013) Russia, Iran and Central Asia: Impact of the U.S. Withdrawal from Afghanistan. Iran Regional Forum. No. 3.

13. RUMER, E. (2002) Flashman's Revenge: Central Asia after September 11. Strategic Forum. No. 195.

14. RICE, C. (2011) No Higher Honor: A Memoir of My Years in Washington. New York: Broadway Paperbacks.

15. MCMULLIN, R. (2003) Caspian Sea Regional Security in the XXIst Century. Carlisle: US Army War College.

16. RUMER, E. (2006) China, Russia and the Balance of Power in Central Asia. Strategic Forum. № 223.

17. ATKIN, M. (1992) Tajikistan's Relations with Iran and Afghanistan. Washington D.C.:The National Council for Soviet and East European Research.

18. GROGAN, M. (2000) National Security Imperatives and the Neorealist State: Iran and Realpolitik. Unpublished Thesis (PhD), Naval Postgraduate School.

19. Central Asia and the Transition in Afghanistan. A Majority Staff Report Prepared for the Use of the Committee on Foreign Relations. (2011) United States Senate. One Hundred Twelfth Congress, First Session, December 19, 2011 [Online] - Available from: http://www.gpo.gov/fdsys/pkg/CPRT-112SPRT71639/html/CPRT-112SPRT71639.htm （Accessed December 12, 2013). 
20. MYERS, P. (2011) Why Hairatan Gate Matters [Online] - Available from: http://www.dcvelocity.com/articles/20111118why_hairatan_gate_matters (Accessed November 11, 2013).

21. PEYROUSE, S., IBRAIMOV, S. (2010) Iran's Central Asia Temptations. Current Trends in Islamist Ideology. Vol. 10. P. 87 - 101.

22. International Contact Group on Afghanistan held meeting of unprecedented level - Kazakh FM (2011) [Online] - Available from: http://inform.kz/eng/article/2419432 (Accessed December 20, 2013).

23. Turkmenistan Plans Gas Pipeline to Iran (2009) [Online] - Available from: http://qctimes.com/business/investment/turkmenistan-plans-gas-pipeline-to-iran/article_fb11d4a0-6f3d11de-8f4b-001cc4c03286.html (Accessed June 5, 2017).

24. President: Turkmenistan Attaches Great Importance to U.S. Cooperation (2014) [Online] Available from: http://en.chrono-tm.org/2014/02/president-turkmenistan-attaches-great-importance-to-us-cooperation (Accessed June 5, 2017).

25. BENDINI, R. (2013) Turkmenistan: Selected Trade and Economic Issues. Policy Briefing Brussels: Directorate-General for External Policies.

26. RAMANI, S. (2016) Has Iran Finally Found a Security Partner in Central Asia? [Online] Available from: http://thediplomat.com/2016/05/has-iran-finally-found-a-security-partner-in-central-asia (Accessed June 5, 2017).

27. CARPENTER, T.G. (2014) The West and Iran in Central Asia: More Competition of Coordination? [Online] - Available from: https://www.boulevard-exterieur.com/The-West-and-Iran-inCentral-Asia-more-competition-or-coordination.html (Accessed June 5, 2017).

Надійшла до редколегії 27.01.2017

Галина Мінгазутддінова, кандидат історичних наук, історик науково-дослідної частини історичного факультету Київського національного університету імені Тараса Шевченка

\section{СТРАТЕГІЧНЕ ЗМАГАННЯ США ТА ІРАНУ В ЦЕНТРАЛЬНІЙ АЗІЇ}

Наприкіниі 1990x - на початку 2000х рр. пострадянські держави Центральної Азіі перетворилися на арену специфічного геополітичного протистояння, відомого як Нова Велика Гра. Зникнення радянського союзу з політичної карти світу призвело до створення нових незалежних держав та появі нових бажаючих серед поза регіональних країн заповнити вакуум, щу лишився після розпаду наддержави. 3'явився иілий ряд держав, щзо прагнули протистояти впливу США в регіоні. Зокрема, мова йдеться про Китай, Росію, Туреччину та Іран. У той час як Сполучені Штати розбудовували свою політику щзодо Центральної Азї̈ трунтуючись на реаліях новітньої історії, їхні конкуренти, зокрема Іран, мав величезний історичний спадок, що пояснював його інтерес до Таджикистану, Казахстану, Узбекистану, Туркменістану та Киргизстану. Однак лише наявність спільної історичної спадщини мало впливає на реальні геополітичні успіхи в регіоні. Поперше, самі країни Центральної Азї вирішили дотримуватися багатовекторності в зовнішній політиці, отримувати будь-яку допомогу від зовнішніх гравців для покращення власного іміджу на міжнародній арені без огляду на будь-яке спільне минуле. По-друге, вирішальним для оформлення домінуючої зовнішньої сили в Центральній Азії є фінансова та військова допомога. По-третє, загальні геополітичні прагнення найвпливовіших держав світу в Центральній Азї виявилися надто переплетеними між собою, $і$ відтак потребували скоріме співпрачі, ніж конкурениії, для їх втілення. Таким чином, поєднання партнерської праці з протидією одне одному між зовнішніми гравиями в Центральній Азї виявилося невідворотним.

Ключові слова: США, Центральна Азія, Іран, Близький Схід, співпрачя. 